\title{
An Introspection of Ecology: the Paradoxes and Conflicts in Snake by D. H. Lawrence
}

\author{
Lei Guo ${ }^{1}$, Xiaomeng $\mathrm{Xu}^{2 *}$
}

${ }^{1}$ Professor, School of Foreign Languages, North China Electric Power University, No.689, Huadian Road, Lianchi District, Baoding city, Hebei Province, China

${ }^{2}$ Post-Graduate Student, School of Foreign Languages, North China Electric Power University, No.689, Huadian Road, Lianchi District, Baoding city, Hebei Province, China

\author{
DOI: $10.36348 /$ sijll.2020.v03i06.003 \\ | Received: 06.06.2020 | Accepted: 13.06.2020 | Published: 21.06.2020
}

*Corresponding author: Xiaomeng Xu

\section{Abstract}

The praise for the vigorous natural life is the theme of D. H. Lawrence's poetry, Birds, Beasts and Flowers. Snake is one of the best poems in this collection of poems which shows an introspection of the relationship between human and nature. This paper aims to analyze the paradoxes and conflicts in Snake and arouse human's attention to ecology. Many studies on Snake focus on ecological consciousness, the symbolic image of snake, sexual consciousness, religious consciousness and Lawrence's natural value. However, a few studies pay attention to its ecological ethics, especially the paradoxes and conflicts in this poem. This paper intends to analyze the paradoxical image of snake in traditional concept and Lawrence's writing, the paradoxical personalities of human in the modern society and the conflicts between anthropocentrism and naturalism. Lastly, this paper tries to give some suggestions to human based on ecological ethics.

Keywords: D. H. Lawrence; Snake; Paradox; Ecological ethics; Naturalism; Anthropocentrism.

Copyright @ 2020: This is an open-access article distributed under the terms of the Creative Commons Attribution license which permits unrestricted use, distribution, and reproduction in any medium for non-commercial use (NonCommercial, or CC-BY-NC) provided the original author and source are credited.

\section{INTRODUCTION}

D. H. Lawrence is famous for his good fictions in English literature. However, he is also a prolific poet with more than 1000 poems during his short life. Unfortunately, his poetry is rarely mentioned.

Keith Sagar [1] remarks that the language of Lawrence's poetry is "necessarily holistic and biocentric" and "speak out with the voice of human nature". In the modern industrial civilization, he resists the rationality and respects humanity. He shows great love to nature. His poem, Snake, which was written in the beautiful island Sicily in Italy, is actually a representative poem of Lawrence's ecological writing. In Snake, he describes his psychological course during his encounter with a snake. He respects and appreciates this snake. They keep a relaxing and harmonious relationship firstly. Then, he feels afraid, horrible and awful to the snake and he obeys the voice of his education, he picks up a clumsy log and throws it to the snake and the snake runs away. At last, he suddenly regrets and hates his vulgar and mean act. He begins to reflect on his behaviors to the nature. It is full of contradictions and conflicts in this process. It can be seen Lawrence's ecological ethical consciousness from these inner struggles and conflicts with the snake.

\section{Literature Review of Snake}

Snake written by D. H. Lawrence is a famous poem in his collection of poems, Birds Beasts and Flowers. Although his fictions are considered as the classics, his poetry expresses his thoughts to religion, sex, industrial civilization and nature. Therefore, it is necessary to explore his ecological ethical thoughts from his poetry. In recent years, Snake is a heated poem in scholars' eyes. They mainly focus on the image of snake and its representation of snake, ecological consciousness, ethical appeals, the conflicts between sexual consciousness and religious consciousness and his natural value.

Zhu Longfa [2] studies the writing style and features of this poem. Dramatic dialogue is adopted in this poem to reveal man's two different characteristics. The poem abandons the traditional poem's form and metric. Repetitions are frequently used in this poem and famous for its rich meanings [2]. 
Chen Hong [3] illustrates the image of snake from two aspects in her On D. H. Lawrence's Poem Snake and Its Representation of the Snake. She illustrates the image of snake from two aspects. The snake in the traditional concept represents an evil, horrible, and cunning monster. The symbolic meaning in Lawrence's poem is noble, elegant and has an equal status with man.

Zi Yunnan [4] studies this poem from the perspective of the contradictions of religious consciousness and sexual consciousness in his paper, On the Conflict Between Two Consciousnesses in D. H. Lawrence's Poem Snake.

Ecological consciousness and natural value of Lawrence are also studied a lot. The paper, On the Ecological Consciousness in Lawrence'S Poem Snake Zi Yunnan, [5] interprets the process of the encounter with the snake embeds the history of the interaction between nature and human being. He divides this process into three periods that are harmony, conflict and introspection.

The paper, Paradoxical Images and Ethical Appeals in D. H. Lawrence's Poem "Snake" Chen Guicai, Huang Jiezhong, [6] describes the paradoxical image of the snake, the paradoxical image of "I", and the paradoxical relation between "I" and the snake based on the literature ethics. They also explore Lawrence's ethical appeals for the return of humanity. Their paper provides a new perspective to analyze the paradoxes in this poem. However, there are few studies which mention this point. Therefore, a systematic research should be advanced.

After reviewing the previous researches, there are a few studies on Lawrence's poems. His outstanding poem Snake represents his critique to the distorted humanity because of industrial civilization and his ecological consciousness for a harmony between man and nature. This paper intends to reveal the paradoxes deeply and explores an approach to build a comfortable and harmonious relationship between man and nature based on ecological ethics.

\section{Ecological Ethics}

Ecological ethics, as its name implies, is the combination of ecology and ethics. It is actually a moral theory about the relationship between man and nature. It discusses how to treat ecological values, how to adjust the relationship between people and biological communities, and how to adjust the relationship between people and the natural environment. Compared with traditional ethics, ecological ethics expands its range to the relationship between man and nature. Human's behaviors in work and life are required under the rule of ecological ethics.
Ecological ethics requires humans to respect nature and other natural beings, protect the survival rights of other natural beings, change their traditional ideas on nature, adjust their practices in their life and try their best to maintain the balance of ecological system.

All in all, ecological ethics is a series of moral norms for humans to deal with the relationship between themselves and their surroundings or nature. With ecological ethics guiding, humans can restrict their unfriendly practices and try their best to obey the norms and have a harmonious relationship with nature.

\section{The Paradox of Traditional Image of Snake and the Snake in Lawrence's Poem The Traditional Image of Snake}

It is known that snake in western culture represents an evil monster. It is brutal and full of desires and temptations with an ugly appearance.

In Bible, snake is Santa who is the culprit of man's sin. Adam and Eve lost their Eden garden because of Santa's temptation. In the Paradise Lost, Santa becomes a dragon to revenge and his followers become snakes finally. Therefore, dragon as a variant of snake is also considered as a devil in western culture. In Exodus, Moses' scepter is the incarnation of snake when Moses led Jews fight with Egyptians. In ancient Egypt, snake is also considered as the authority.

In ancient Greek mythology, Typhon, Echinda and Hydra are the snakes which are evil to hurt humans, destroy fields and cattle. They are very cruel. In addition, snake always spoils some beautiful things. For example, Orpheus and Eurydike love each other best like love birds. Unfortunately, Eurydike was beaten by a snake in her wedding. She dies and leaves her loved Orpheus in the world. It is very sad that their love is spoiled by a snake.

In this poem, Lawrence describes this snake as "being earth-brown, earth-golden from the burring bowels of the earth" "His tongue like a forked night on the air, so black" "He put his head into that dreadful hole" "writhed like lighting, and was gone into the earth-lipped fissure in the wall-front". (Lawrence, 1994) [7] From his descriptions, it can be seen that this snake is very horrible and scared. It has a golden soft body like the burning bowels of the earth. At the same time, the snake reminds Lawrence of Etna smoking volcano which is an awful natural disaster. The voice of education tells that the golden snakes in Sicily are venomous. Thus, the voice of education is the traditional rational ideas about snake. His forked tongue brings dangers to humans. The place where snakes live is a dark and secreted hole. This hole brings mysterious and horrible feelings because human cannot control this unknown field. 
From the traditional ideas on snake, it can be proved that snake is a devil and brings dangers to humans.

\section{The Snake in Lawrence's Poem}

Influenced by romanticism, Lawrence describes his snake as noble and man-like in his poem. First of all, snake is given the equal status with human and has some human characters. In the poem, "and must wait, must stand and wait for there, he was at the trough before me" [7]. It is shown that the poet respects the snake. The snake has the equal status as human, because poet uses "must wait" to show his emotion to this snake. The snake comes there before poet so he should have the priority to drink water. In addition, the poet uses "he" to name the snake. In a sense, the snake is given human characters and the poet appreciates and welcomes him. Secondly, the poet shows his like to the snake. The poet describes this snake's body with a "yellow-brown slackness soft-bellied".[7] The poet also observes how the snake drinks water very intently. The snake "rested his throat upon the stone bottom. He sipped with his straight mouth, softly drank his straight gums, into his slack long body. Silently" [7]. Through his observation, it can be found that the poet appreciates and enjoys the time when his encounter with the snake. Besides, the simile and personification are adopted to beautify the snake. "He lifted his head from his drinking, as cattle do, and looked at me vaguely, as drinking cattle do.'[7] Poet links snake which is evil, terrified and horrible in human's thought to cattle which are mild animals to humans. He "mused a moment". Poet thinks the snake can think like humans, so here, the poet is friendly to the snake. "But I must confess how I liked him, How glad I was he had come like a guest in quiet to drink at my water-trough, And depart peaceful, pacified, and thankless"[7]. Form this paragraph, it can be seen that the poet is honored to meet this snake and invites him to drink water. The poet even doesn't need thanks from the snake because he respects and admires the snake. Lastly, the poet endues the divine characteristics to the snake. "And looked around like a god, unseeing, into the air, and slowly turned his head, and slowly, very slowly, as if thrice a dream" [7]. A calm and elegant snake is shown in front of poet. In addition, the poet believes this snake "like a king, like a king in exile, uncrowned in the underworld, Now due to be crowned again" [7]. Poet compares snake with an exiled king, and believes that he will crown again sooner or later. Even though the snake flees in panic, he will show his great power and manner again. In Lawrence's poem, snake is "one of the lords of life" [7]. He is so elegant and calm, and can control his life freely.

In conclusion, Lawrence shows his honor and respect to the snake which is sacred and inviolable. Although he is under the pressure of the social prejudice, this snake will gain his honor and authority again one day. However, Lawrence also describes the awful appearance of snake. In this way, the snake has the common characteristics with the traditional image of snake. Therefore, this snake is a paradox in Lawrence's poem. This paper has an idea that even though the snake has an ugly and scared appearance, human should appreciate his elegance and respect his survival right. Humans should give up their arrogant and vulgar practices to nature.

\section{The Paradox of Human's Personalities in Nature The performance of Id}

Id represents the nature of the man and shows the natural feelings of humans. In the poem, poet enjoys observing snake and treats snake as a guest. The poet is honored that the snake comes to his trough. He waits the snake and let the snake drink water firstly. Even he doesn't require thanks from the snake, which shows his great rejoicing during their time. The poet performs as a gentleman to treat this snake generously. In his inner world, the snake is equal to him and they are parts of nature.

Id is an animals' instinct to accord with the principal of happiness. In the poem, poet likes and appreciates the snake without any reasons but just follows his heart. Lawrence's snake is not only different from the devil of traditional concept but also different from the aggressive impression in humans' cognition. "Lawrence's snake represents our instincts of bloody consciousness which also exists in animals" [3]. In a sense, Lawrence tries to stress the importance of human's nature which is a reflection on the distortion of humanity. Therefore, Id plays a vital role in the harmonious relationship with nature.

\section{The Performance of Ego and Superego}

Ego is constrained by the social rules. What humans want to do should obey the moral rules. In the poem, "the voice of education" is mentioned many times. "The voice of my education said to me, He must be killed, for in Sicily the black, black snakes are innocent, the gold are venomous" [7]. In fact, that voice is from humans' traditional concept. At that time, ego suppresses id. The reality or the reason surmounts the sensibility. When the poet is hesitating, the voice appears again. "If you were a man, you would take a stick and break him now and finish him off' [7]. The poet is still feeling so honored to get along with the snake. However, the behavior that the snake puts his head into that dreadful hole, eases his shoulder and slowly draws up his body makes me feel a sort of horror. The poet "protests against his withdrawing into that black hole deliberately going into that blackness, and slowly drawing himself after, overcome me now his back was turned" [7]. This paper assumes that the poet wants to talk with him but the snake wants to leave and goes into the dreadful black hole after drinking water, which offences poet as if he is rejected by a snake. Therefore, the poet "picked up a clumsy log and threw it at the water-trough with a clatter" [7]. At that 
moment, anthropocentrism occupies poet's mind and his acts conform to the traditional value which he is told to be believed.

The poet immediately regrets to do that. "I thought how paltry, how vulgar, what a mean act! I despised myself and the voices of my accursed human education" [7]. In a sense, superego begins to play a role in poet's mind. Superego is the idealized image that a person builds himself in response to authority and social pressures. Superego represents conscience and acts according to the principle of kindness to guide them. Under the superego's guidance, poet thinks of the albatross. The albatross is a bird in Samuel Taylor Coleridge's poem The Rime of the Ancient Mariner. A mariner kills an albatross as a result of the death of all mariners in their boat except that ancient mariner. The poet is afraid that his hit will bring the bad luck to humans. The albatross here inspires human should respect the creatures in nature. If they abandon the moral rule, they will be punished by the nature. Therefore, in this poem, the poet regrets to hurt that snake and now he wants that snake to come back. He reflects on the relationship between him and that snake. That snake is like one of the lords of life and the poet loses that chance to talk with him. Humans lose the chance to talk with the nature because of their pettiness.

In this poem, it can be found that the poet hesitates among id, ego and superego. The poet gets along with the snake happily out of his heart. When he hits the snake, he explodes his evil personality. The voice of education governs his mind and damages the snake. Lastly, inspired by the superego, he regrets and respects on his mistakes to nature. In conclusion, the poet is a paradox with kind and evil personalities in nature. He struggles for a comfortable way to get on with nature.

\section{The Conflicts between Anthropocentrism and Naturalism}

When it comes to ecological ethics, anthropocentrism and naturalism are the basic items to be mentioned. At the beginning, humans obey natural laws. In the poem, the poet treats the snake as a guest, god, king and even the lord of life. He waits the snake to drink and observes him carefully. He appreciates the snake's calmness and elegance although the snake is in exile. When naturalism occupies human's minds, they usually respect and admire nature. They extend their generous and inclusive personalities to nature. In that way, a harmonious relationship between human and nature is built.

However, with the industrial revolution developing, humans start to challenge the nature and desire to conquer nature. They destroy environment to pursue their interests. At that moment, anthropocentrism has a priority status. Humans are the center of the world. They set a lot of criteria and values.
It is thought that humans are superior to the nature in anthropocentrism. The relationship between poet and snake can be considered as the relationship between human and nature. In the poem, when poet feels scared to that snake, he hits the snake with a log under the force of his voice of education. He believes that the snake forms a threat to him and he must kill the snake to protect himself. However, the snake doesn't do any bad things to the poet. When the scarce is more than respect, anthropocentrism will make a big difference. It forces humans to conquer nature.

In the conflicts between anthropocentrism and naturalism, the poet starts to reflect on the relationship between humans and nature. "I wished he would come back, my snake" [7]. However, the snake leaves away quickly after being hit by the poet. Only the remorse and pity are leaved in poet's mind. His remorse proves that naturalism overbears anthropocentrism. The human nature is returning.

In ecological ethics, Marviyn, M. and Bergel, $\mathrm{K}$ [8] believe "respect life, remain life, promote life, and make the life reach the highest development." are the main ecological ethical values. It stresses out that all life is sacred and awesome as long as they coexist with humans in a world. From enjoying snake, hitting snake and then regretting, it reveals humans should revere life and aware of the importance of nature. The poet encourages humans to return to their initial relationship with nature.

Ecological ethics confirms that ecosystem is a complex organic integrity. In this complex system, humans are the member of the nature. Humans depend on nature to exist and must follow the laws of nature. Learning to respect the natural values and rights of other natural beings is a good lesson for humans to get along with nature.

\section{CONCLUSION}

In $20^{\text {th }}$ century, Lawrence extends his ecological consciousness in his poems. Through the deep analysis of the poem Snake in the perspective of ecological ethics, this paper aims at revealing paradoxes and conflicts in the poem. Lawrence's snake both has the traditional image of devil and holy image. The poet has the double personalities during getting on with the snake. In addition, the conflicts between anthropocentrism and naturalism have made the poet reflect on humans' acts to nature.

Ecological ethics requires humans to bear the responsibilities to respect all lives in the nature without discrimination. Social development must follow the natural laws. The sustainable social development need humans give up the concept of anthropocentrism and advocate naturalism. 
This poem, Snake gives an inspiration to humans that leading a harmonious life with nature makes a big difference to the world.

\section{REFERENCES}

1. Sagar, Keith. (2007). D. H. Lawrence: Poet. Tirril: Humanities-ebooks.

2. Zhu, L. F. (1986). Reading Lawrence's "Snake" Poetry-A Random Talk on Its Writing Features. Journal of Nanwai University, 3: 29-33.

3. Chen, H. (2007). On D. H. Lawrence's Poem Snake and Its Representation of the Snake. Foreign Literature Studies, 6: 130-139.

4. Zi, Y. N. (2009). On the Conflict between Two Consciousnesses in D. H. Lawrence's Poem
Snake. Journal of Hunan Institute of Engineering, 19(4): 39-42.

5. Zi, Y. N. (2010). On the Ecological Consciousness in Lawrence'S Poem Snake. Journal of Hengyang Normal University, 31(2):136-139.

6. Chen, G. C., \& Huang, J. Z. (2017). Paradoxical Images and Ethical Appeals in D. H. Lawrence's Poem "Snake". Journal of Yichun University, 39(1): 100-103+117.

7. Lawrence, D. H. (1994). The Complete Poems of D. H. Lawrence. Wordworth Editions Ltd.

8. Marviyn, M., \& Bergel, K. (2002). Reverance for Life: The Ethics of Albert Schweitzer for the Twenty-First Century. New York: Syracuse University Press. 